\title{
What mechanistic factors affect thelytokous parthenogenesis in Apis mellifera caponises queens?
}

\author{
Sarah E. Aamidor ${ }^{1}$, Michael H. Allsopp ${ }^{2}$, Rebecca J. ReID ${ }^{1}$, Madeleine BeEKman ${ }^{1}$, \\ Gabriele Buchmann ${ }^{1}$, Theresa WossLer ${ }^{3}$, Benjamin P. Oldroyd ${ }^{1}$ \\ ${ }^{1}$ Behaviour and Genetics of Social Insects Laboratory, Ecology and Evolution, University of Sydney, Macleay Building \\ A12, Sydney, NSW 2006, Australia \\ ${ }^{2}$ Honeybee Research Section, ARC Plant Protection Research Institute, Private Bag X9017, Stellenbosch 7599, South \\ Africa \\ ${ }^{3}$ Department of Botany and Zoology, Stellenbosch University, Private Bag XI, Matieland 7602, South Africa
}

Received 5 May 2019 - Revised 28 August 2019 - Accepted 7 November 2019

\begin{abstract}
The Cape honey bee (Capensis) is unusual in that workers can produce viable female offspring via thelytokous parthenogenesis. In contrast, mated queens never reproduce thelytokously, even though they could benefit from doing so when generating daughter queens. Nonetheless, virgin Capensis queens induced to lay without mating by $\mathrm{CO}_{2}$ narcosis produce a high proportion of thelytokous eggs, and instrumentally inseminated queens produce triploid offspring as the result of the fusion of two egg pronuclei and a sperm nucleus. We show here that thelytoky/triploidy in Capensis queens is not a consequence of $\mathrm{CO}_{2}$ narcosis per se because narcosis of laying queens does not induce thelytokous or triploid progeny. We also show that in artificially inseminated queens, the frequency of thelytoky/triploidy declines with age and is absent 10 months post-insemination. We confirm that the presence of semen in the spermatheca is not the mechanism that prevents thelytoky/triploidy in mated queens.
\end{abstract}

\section{Apis mellifera / Honey bee / Triploidy / Thelytoky / Parthenogenesis / Haplodiploidy}

\section{INTRODUCTION}

The order Hymenoptera (ants, bees and wasps) is haplodiploid. Males are haploid, derived from unfertilized eggs by arrhenotokous parthenogenesis, whereas females are diploid and are derived from fertilized eggs. Another form of parthenogenesis that is uncommon but taxonomically widespread in Hymenoptera is thelytoky (Kronauer et al. 2012). Under automictic (with

Electronic supplementary material The online version of this article (https://doi.org/10.1007/s13592-019-00719-3) contains supplementary material, which is available to authorized users.

Corresponding author: S. Aamidor, sarah.aamidor@sydney.edu.au Handling editor: David Tarpy meiosis) thelytoky, unfertilised eggs develop into diploid females by the fusion of two maternal pronuclei following meiosis (Tucker 1958; Verma and Ruttner 1983; Goudie and Oldroyd 2014; Cole-Clark et al. 2017). The resulting offspring are essentially clones of the mother, though there can be loss of heterozygosity as a result of recombination (Pearcy et al. 2006; Goudie and Oldroyd 2014). Among social Hymenoptera, thelytoky is most common in ants (reviewed by Rabeling and Kronauer 2013). In honey bees (Apis species), thelytoky occurs at high frequency in only one subspecies, A. mellifera capensis (hereafter Capensis) (Hepburn and Crewe 1991; Hepburn 2001).

In the absence of a queen, Capensis workers quickly start to lay thelytokous eggs that result in diploid females (Anderson 1963; Verma and 
Ruttner 1983; Goudie and Oldroyd 2014). In contrast, queenless workers and virgin queens of other honey bee species and subspecies lay arrhenotokous haploid eggs that result in males, though there are rare exceptions (Mackensen 1943; Tucker 1958; DeGrandi-Hoffman et al. 1991; Holmes et al. 2015; Gloag et al. 2017; Gloag et al. 2019). Unlike workers, mated Capensis queens do not produce thelytokous offspring (Jordan et al. 2007; Beekman et al. 2009; Holmes et al. 2010).

The ability of Capensis workers to reproduce thelytokously raises interesting questions as to why Capensis queens do not do so in the field (Goudie and Oldroyd 2018). Queen thelytoky has evolved in some populations of at least seven ant species, where queens are produced asexually by thelytoky, whereas the workers are produced sexually (Pearcy et al. 2004; Fournier et al. 2005; Kobayashi et al. 2008; Leniaud et al. 2012; Eyer et al. 2013; Okita and Tsuchida 2016; Lacy et al. 2019). Clearly, social insect queens can benefit from thelytoky because they are genetically reincarnated if they are replaced by a thelytokous daughter queen (Greeff 1996). It is particularly curious that Capensis queens do not produce queen offspring thelytokously for two reasons. First, Capensis workers routinely reproduce thelytokously when queenless. Second, thelytoky can be induced in virgin Capensis queens by $\mathrm{CO}_{2}$ narcosis (Crewe and Allsopp 1994; Oldroyd et al. 2008). Therefore Capensis queens have genetic and physiological mechanisms available to them that allow them to lay thelytokously and should do so if it increases their fitness. But they do not do so. Why? Goudie and Oldroyd (2018) have argued that queen thelytoky and worker thelytoky are unlikely to be present in the same species simultaneously. If queens and workers are both thelytokous, they produce identical offspring, and there is no genetic benefit (such as genetically diverse offspring, Oldroyd and Fewell 2007) to retaining the queen caste. Because the collective workers always have greater reproductive capacity than a single queen, a breakdown in reproductive division of labour is likely to ensue, leading to the loss of the queen caste or to extinction of the thelytokous population (Goudie and Oldroyd 2018). This opens the question as to what proximate mechanisms may prevent thelytoky in naturally mated Capensis queens. Potentially, the presence of semen in the spermatheca is the proximate mechanism that prevents queen thelytoky in naturally mated queens and artificially inseminated queens, among other possible mechanisms that we explore below.

Artificial insemination of honey bee queens requires two rounds of narcosis with $\mathrm{CO}_{2}$ (Harbo 1986). Typically the queen is immobilized by $\mathrm{CO}_{2}$ narcosis for a few minutes during the insemination procedure and again the next day for 4-10 minutes (Harbo 1986). Unless so treated, queens do not normally initiate oviposition (Mackensen 1947) until they are over 25 days old (Mackensen 1943). However it is currently unknown whether virgin Capensis queens that have the ability to lay thelytokously will eventually initiate oviposition without $\mathrm{CO}_{2}$ narcosis, and if so whether they will reproduce thelytokously or arrhenotokously. A virgin Capensis queen that produced thelytokous offspring could potentially generate a viable colony and a replacement daughter queen.

Oldroyd et al. (2018) found that in Capensis queens that are instrumentally inseminated using $\mathrm{CO}_{2}$ narcosis, 5-33\% of the pupal progeny Capensis queens are triploid. This phenomenon is unrelated to the subspecies origin of the semen used for insemination (Oldroyd et al. 2018). It occurred in all 12 instrumentally inseminated Capensis queens treated with $\mathrm{CO}_{2}$ but in none of the four queens from the arrhenotokous A. m. scutellata population, linking triploidy to thelytoky. A combination of genetic analysis and flow cytometry showed that triploids arose as a result of the thelytokous fusion of two maternal pronuclei together with a sperm nucleus. Interestingly, no diploid thelytokous progeny were observed, suggesting that thelytokous fusion zygotes always fuse with a sperm in inseminated queens.

Since we know that naturally mated Capensis queens never reproduce by thelytoky but that $\mathrm{CO}_{2}$ narcosis induces thelytoky in virgin queens and in artificially inseminated queens (as evidenced by triploidy) (Crewe and Allsopp 1994; Oldroyd et al. 2008; Oldroyd et al. 2018), we are led to ask whether it is the $\mathrm{CO}_{2}$ narcosis itself that 
induces thelytoky as was strongly suggested by our previous study (Oldroyd et al. 2018). Alternatively, induction of oviposition without mating may be the factor that induces thelytoky. That is, if oviposition could be induced in Capensis virgin queens without $\mathrm{CO}_{2}$ narcosis, would the offspring be thelytokous or arrhenotokous?

Here we examine five related questions about the intersection of mating, onset of oviposition, $\mathrm{CO}_{2}$ narcosis, thelytoky and triploidy in Capensis. First we determine whether the instrumental insemination of virgin queens that are laying thelytokously following $\mathrm{CO}_{2}$ narcosis switches off thelytoky as a consequence of the presence of semen in the spermatheca, so that all female progeny are produced sexually, as in mated queens. If so, this would indicate that there is a factor in semen that prevents thelytoky in mated queens. Second we asked whether virgin Capensis queens that are not treated with $\mathrm{CO}_{2}$ would eventually commence oviposition, and if so whether they would produce progeny thelytokously or arrhenotokously. Third, we determine whether thelytoky or triploidy is a phenomenon of young instrumentally inseminated queens only, or if the phenomenon disappears as queens age as has been reported in A.m. ligustica (Tucker 1958). Fourth, we investigate whether mature, naturally mated Capensis queens that have been producing fertilized diploid eggs for at least 3 months can be converted to thelytokous reproduction or to the production of triploid offspring following $\mathrm{CO}_{2}$ narcosis. Finally, we ascertain the frequency of triploidy in the first brood of naturally mated Capensis queens.

\section{METHODS}

Capensis has a natural range in the three southern provinces of South Africa, south of the Karoo ecotone (Allsopp 1993; Hepburn et al. 1994; Hepburn et al. 1998; Beekman et al. 2008). All experiments were conducted at the Plant Protection Research Institute in Stellenbosch South Africa. This area is well within the natural range of Capensis, where all colonies produce thelytokous worker-laid brood if they are dequeened.

\subsection{Genotyping}

We extracted DNA from single eggs, pupa and drones using the Chelex method (Walsh et al. 1991). We genotyped each individual at several polymorphic microsatellite loci split across two multiplexes: for Experiment 1, we used A79, A8, A14, A113, A88 and B124. For Experiments 2-4, we used A79, A8, A113, A88, Ap43 and B124 (Solignac et al. 2003; Shaibi et al. 2008) (primer sequences and PCR conditions in supplementary Table SI). PCR products were electrophoresed on a 3130XL DNA analyser (Applied Biosystems, Foster City, CA, USA) and data captured using GeneMapper ${ }^{\mathrm{TM}}$ software 3.7 (Applied Biosystems).

\subsection{Experiment 1. Instrumental insemination of virgin queens laying thelytokous eggs: does semen prevent thelytoky?}

We introduced queen pupae or newly eclosed adult Capensis queens into each of four threeframe mini-nuclei stocked with c.a. 1000 young workers of the A. m. scutellata subspecies (hereafter Scutellata). Scutellata workers are strictly arrhenotokous and rarely activate their ovaries in the presence of a queen. We prevented the queens from leaving their hives by clipping their wings (the wing clipping was saved for later genotyping) and placing a queen excluder grid over the entrance that allowed the passage of workers but not the larger queens. We established four such colonies in a screen tent $(10 \mathrm{~m} \times 10 \mathrm{~m} \times 2 \mathrm{~m})$. The screen tent ensured that no reproductive parasite workers from Capensis colonies entered our experimental colonies.

When the queens were 7 days old, we subjected them to two 10-minute periods of narcosis with carbon dioxide on consecutive days to induce oviposition (Mackensen 1947). Further, 10-minute treatments were given at 7-day intervals until the queens commenced egg laying. Queens 13, 14 and 15 had two additional narcoses; queen 6 had five additional narcoses.

Once the queens began laying, we separately collected eggs and larvae from drone and worker 
comb from each colony into $95 \%$ ethanol. We collected eggs $>24$ hours old to ensure enough embryonic tissue was present to allow genotyping and that no maternal genetic material remained (though it is most unlikely that a PCR product would be produced from just three polar bodies). We aimed to collect at least 100 eggs per colony, although this was not always possible as some queens did not lay many eggs in one or other cell type or died before the required number of eggs had been collected.

When the queens were approximately 2 months old, we instrumentally inseminated the three surviving queens, each with the semen of between 7 and 10 brother drones from different Capensis colonies (Figure 1). The fathering drones were retained for genotyping.

Following insemination, we again attempted to collect at least $100>24$-hour-old eggs per colony, per cell type, into $95 \%$ ethanol. Any queen that was alive at the end of the experiment was retained for genotyping, or her genotype was obtained from wing clippings or reconstructed from her progeny's genotypes.

We compared each egg genotype to its mother's genotype. Eggs that possessed one of the two queen alleles across all loci were classified as hemizygous males arising from arrhenotokous parthenogenesis. Any male egg that did not possess either of the two queen alleles at all six loci was classified as an offspring of host workers and excluded from analysis. Eggs that were heterozygous at one or more loci were classified as female. Female eggs that possessed one queen allele in the homozygous state or both queen alleles across all loci were classified as female offspring of the queen arising from thelytokous parthenogenesis (Figure 1). Genotypes of female eggs collected post-insemination were compared with both the queen's (mother) and drone's (father) genotypes. Eggs were then classified as being (1) female eggs produced sexually; (2) male eggs produced arrhenotokously; (3) female eggs produced thelytokously and (4) > 2 alleles at any locus (triploid). We required at least three informative loci to classify the reproductive mode by which an egg had been produced (arrhenotokous, sexual or thelytokous). Eggs that did not meet these criteria were discarded from the data set.
Note that there were two ways in which a diploid male could have been present in our samples. First, the queen might carry an identical sex allele as one or more of the seven inseminating males the sex locus (Beye et al. 2003). Since the males were unrelated to the queen, this is unlikely. If it did occur, the egg would be correctly classified as having been produced sexually because it carried paternal alleles. Second, an egg could be thelytokous but become homozygous at the sex locus as a consequence of recombination (Goudie and Oldroyd 2014). If this occurred, the egg would be heterozygous at other loci and would be correctly classified as being thelytokous because no paternal alleles would be present.

\subsection{Experiment 2. Do virgin Capensis queens eventually start laying, and if so do they produce thelytokous offspring?}

Honey bee queens of European subspecies that are prevented from mating by physical means eventually start laying (Mackensen 1943), even without $\mathrm{CO}_{2}$ narcosis. Given their ability to lay thelytokously, we predicted that virgin Capensis queens would eventually commence laying thelytokously if prevented from mating. To test this hypothesis, we reared five virgin Capensis queen pupae by standard methods (Harbo 1986). We introduced queen pupae to queenless colonies of Capensis workers. After the young queens emerged, we marked them, clipped their wings and confined them to their hives with a queen excluder grid that prevented them from leaving their hive to mate. We examined the colonies comb by comb on a weekly basis to determine the presence or absence of eggs or other brood items and the presence or absence of the queen. We terminated these observations after 30 days post-occlusion, dissected each queen and determined the extent of ovary activation under a dissecting microscope. No brood items were found so no genetic analysis was possible. 


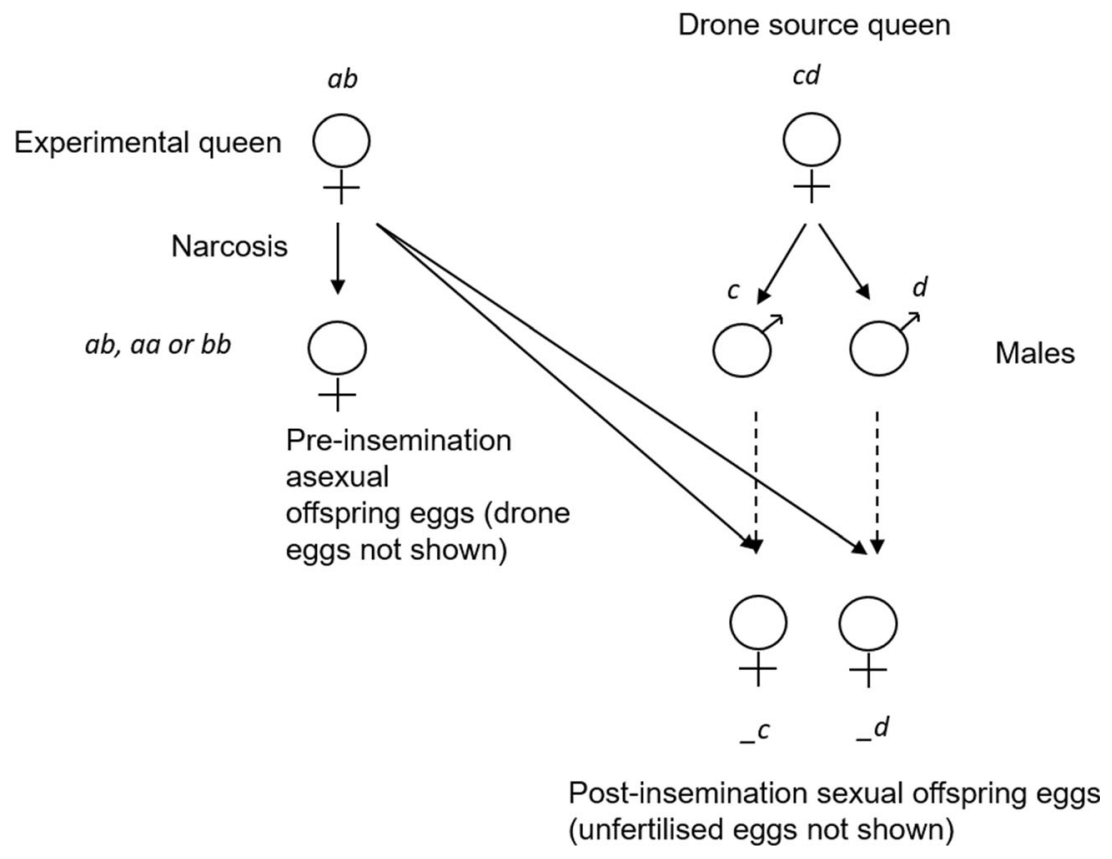

Figure 1. Crosses for Experiment 1.

(unfertilised eggs not shown)

\subsection{Experiment 3. Is triploidy only a characteristic of young artificially inseminated queens?}

Although triploidy has been found in the progeny of young instrumentally inseminated Capensis queens (Oldroyd et al. 2018), it is possible that this phenomenon is short-lived and that this explains why triploidy is not seen in the progeny of mature naturally mated queens (Beekman et al. 2009). To examine this question further, we genotyped the pupal progeny of two queens that had produced triploid progeny when they were 3 months old (Oldroyd et al. 2018), when the queens were 11 months old and again at 12 months of age to increase sample size.

\subsection{Experiment 4. Does $\mathrm{CO}_{2}$ narcosis induce triploidy in mature, naturally mated, Capensis queens?}

$\mathrm{CO}_{2}$ narcosis induces thelytoky in virgin Capensis queens (Crewe and Allsopp 1994; Oldroyd et al. 2008). Newly inseminated
Capensis queens produce triploid progeny at high frequency, because they produce thelytokous eggs that are then fertilized (Oldroyd et al. 2018). This suggests that $\mathrm{CO}_{2}$ narcosis triggers the production of thelytokous eggs. To test this hypothesis, we selected 8 colonies headed by naturally mated Capensis queens that were more than 3 months old and most likely over 12 months old. From each colony, we caught the queen, permanently marked her and clipped her wing, retaining the wing for genotyping. (Wing clipping does not affect the likelihood that a honey bee queen will lay (Laidlaw and Page 1997).) We then narcotised the queens with $\mathrm{CO}_{2}$ for $10 \mathrm{mi}$ nutes. Narcosis was repeated on the following day, again for 10 minutes. Simultaneously, we harvested 100 worker pupae from each queen for genotyping so that we could establish whether the queens reproduced by thelytoky or produced any triploid offspring. Later we collected pupae for genetic analysis 4 weeks post-narcosis and for some colonies a second time 12 weeks post-narcosis. 


\subsection{Experiment 5. Is triploidy/thelytoky present in the first brood of a naturally mated queen?}

Since triploids are found in young inseminated queens treated with $\mathrm{CO}_{2}$ (Oldroyd et al. 2018), we wondered whether all Capensis queens produce triploid/thelytokous offspring in their first brood but that the frequency of thelytoky rapidly diminishes with age. To test this hypothesis, we dequeened two Capensis colonies so that the workers laid eggs thelytokously and reared virgin queens from the resulting larvae. Following natural mating of the two queens, we collected pupae from their first brood and the queens themselves for genetic analysis. We confirmed that the sampled worker progeny were daughters of the queens and determined whether any workers were triploid.

\section{RESULTS}

\subsection{Experiment 1. Instrumental insemination of virgin queens laying thelytokous eggs}

Prior to insemination, all four virgin queens that had been induced to lay eggs via $\mathrm{CO}_{2}$ narcosis produced both diploid female (thelytokous) and haploid male (arrhenotokous) eggs (Table I, genotypes in Table SII). For the two queens where the sample size was sufficient for a valid test, there was no significant association between cell type (drone size or worker size) and whether the eggs laid was thelytokous or arrhenotokous (Table I), suggesting that unmated queens cannot determine whether their eggs develop thelytokously or arrhenotokously.

Queen 15 died before insemination, and queen 13 died not long after insemination but laid 14 unfertilized eggs in worker comb before she died (Table II). After insemination, queens 6 and 14 laid both thelytokous and fertilized female eggs and arrhenotokous male eggs. There was a significant tendency to lay unfertilized and fertilized eggs in the correct cell type (Table II). Post-insemination, most thelytokous eggs were laid in drone cells, indicating that the queen mostly succeeded in laying unfertilized eggs in drone cells (Table II) but could not prevent thelytoky.

Queens 6 and 14 laid 24 and 27 eggs, respectively (Table II), that carried the two queen alleles and one of the drone alleles at several loci. These triploid eggs were found in both worker and drone comb.

\subsection{Experiment 2. Do virgin Capensis queens eventually start laying, and if so do they produce thelytokous offspring?}

All five virgin queens that were confined to their colonies by a queen excluder grid so they could not mate were alive after 30 days. We did not find eggs in the brood combs of any colony.

Dissections of the queens and examination of the spermathecae and ovaries showed that all spermathecae were clear, indicating that we had successfully prevented the queens from mating. The ovaries of four of the queens were undeveloped with no evidence of eggs. The fifth queen showed swelling of the ovarioles and a small number of eggs that were less than half length, indicating that she was not laying.

\subsection{Experiment 3. Is triploidy only a characteristic of young artificially inseminated queens?}

Oldroyd et al. (2018) reported that two instrumentally inseminated Capensis queens produced 5 and $8 \%$ triploid worker offspring, respectively, when they were 4 months old and 4 months post-insemination. We resampled worker progeny from these same colonies, when the queens were 11 months old and again when the queens were 12 months old (Table III). None of the sampled worker offspring were triploid at the second and third samplings (genotypes in Table SIII). For queen 1, the probability of observing no triploids in a total sample of 189 progeny, while assuming that the previous frequency of $5 \%$ triploids observed when the queen was 
Table I. Mode of reproduction of eggs laid by virgin Apis mellifera capensis queens induced to lay by $\mathrm{CO}_{2}$ narcosis in Experiment 1, pre-insemination

\begin{tabular}{lllll}
\hline Mode of reproduction & \multicolumn{2}{l}{ Number of eggs produced per queen } & \\
\cline { 2 - 5 } & Queen 6 & Queen 13 & Queen 14 & Queen 15 \\
\hline Thelytokous eggs in worker cells & 5 & 2 & 48 & 4 \\
Thelytokous eggs in drone cells & 29 & 4 & 9 & 3 \\
Arrhenotokous eggs in worker cells & 7 & 72 & 31 & 62 \\
Arrhenotokous eggs in drone cells & 36 & 18 & 11 & 79 \\
Fisher's exact test of association between & $P=0.55$ & Insufficient data & $P=0.22$ & Insufficient data \\
cell type and mode of parthenogenesis* & & & & \\
\hline
\end{tabular}

*Test performed using Crosstabs in SPSS

4 months old was maintained 8 months later, is $<0.001$ (binomial test performed in Excel). For queen 2, the probability of observing 0 triploid progeny in a total sample of 163 progeny, assuming that the previous frequency of $8 \%$ triploids was maintained is $<<0.001$. These conclusions are unaltered $(P<0.05)$ for all values within the $95 \%$ confidence intervals for the percentage of triploids in the original samples based on the normal approximation to the binomial distribution (Zar 1996): $1.98-8.02 \%$ for queen 1 and $4.24-8.75 \%$ for queen 2. This demonstrates that the production of triploids in instrumentally inseminated Capensis queens is a temporary phenomenon.

\subsection{Experiment 4. Does $\mathrm{CO}_{2}$ narcosis induce triploidy in mature, naturally mated Capensis queens?}

$\mathrm{CO}_{2}$ narcosis had adverse effects on the eight mature queens we narcotised. Two queens died within 3 weeks; one queen died within 12 weeks. Genotyping revealed that one colony had two queens and numerous worker-laid offspring (Colony 8 in Supplementary Material Table SIV). We therefore examined the progeny of the remaining 4 mature laying queens treated with $\mathrm{CO}_{2}$ narcosis using pupae collected prior to treatment and 26 days post-treatment. For three of these colonies (colonies 1-3), we collected a

Table II. Mode of reproduction of eggs laid by Apis mellifera capensis queens in Experiment 1, post-insemination

\begin{tabular}{|c|c|c|c|c|c|c|c|}
\hline & \multicolumn{2}{|c|}{ Queen 6} & \multicolumn{2}{|c|}{ Queen 13} & \multicolumn{2}{|c|}{ Queen 14} & \multirow[b]{2}{*}{ Total } \\
\hline & $\begin{array}{l}\text { Drone } \\
\text { cells }\end{array}$ & $\begin{array}{l}\text { Worker } \\
\text { cells }\end{array}$ & $\begin{array}{l}\text { Drone } \\
\text { cells }\end{array}$ & $\begin{array}{l}\text { Worker } \\
\text { cells }\end{array}$ & $\begin{array}{l}\text { Drone } \\
\text { cells }\end{array}$ & $\begin{array}{l}\text { Worker } \\
\text { cells }\end{array}$ & \\
\hline Triploid (> 2 alleles at some loci) (A) & 2 & 22 & 0 & 0 & 7 & 20 & 61 \\
\hline $\begin{array}{l}\text { Diploid sexual, mother and father alleles } \\
\text { only at all loci (B) }\end{array}$ & 1 & 15 & 0 & 0 & 17 & 87 & 120 \\
\hline $\begin{array}{l}\text { Thelytokous (queen's alleles only, } \\
2 \text { alleles at some loci) (C) }\end{array}$ & 21 & 1 & 0 & 1 & 16 & 2 & 41 \\
\hline $\begin{array}{l}\text { Arrhenotokous (queen's alleles only, } \\
1 \text { allele at all loci) (D) }\end{array}$ & 21 & 2 & 0 & 13 & 71 & 17 & 124 \\
\hline Fertilized $(A+B)$ & 3 & 37 & 0 & 0 & 24 & 107 & 171 \\
\hline Not fertilized $(C+D)$ & 42 & 3 & 0 & 14 & 87 & 19 & 165 \\
\hline $\begin{array}{l}\text { Fisher's exact test of association } \\
\text { between cell type and egg fertilization* }\end{array}$ & \multicolumn{4}{|c|}{$P<0.001$ Insufficient data } & \multicolumn{2}{|c|}{$P<0.001$} & \\
\hline
\end{tabular}

*Test performed using Crosstabs in SPSS 
Table III. The decline in the frequency of triploid offspring as A. m. capensis queens age

\begin{tabular}{lllllll}
\hline Queen & $\begin{array}{l}\text { Sample } \\
\text { date (2017) }\end{array}$ & $\begin{array}{l}\text { Age of queen at } \\
\text { sample date } \\
\text { (months) }\end{array}$ & $\begin{array}{l}\text { Number of } \\
\text { progeny } \\
\text { genotyped }\end{array}$ & $\begin{array}{l}\text { Progeny of } \\
\text { parasitic } \\
\text { workers }\end{array}$ & $\begin{array}{l}\text { Number of } \\
\text { triploid } \\
\text { progeny }\end{array}$ & $\begin{array}{l}\% \\
\text { triploid }\end{array}$ \\
\hline 1 & $\begin{array}{l}\text { 15 February } \\
\text { 20 September }\end{array}$ & 4 & 200 & 0 & 10 & 5 \\
& 11 & 96 & 0 & 0 & 0 \\
2 & 30 October & 12 & 96 & 0 & 0 & 0 \\
& 15 February & 4 & 200 & 0 & 16 & 8 \\
& 20 September & 11 & 96 & 6 & 0 & 0 \\
\hline
\end{tabular}

second sample 84 days post-treatment (Table IV, genotypes in Table SIV).

In colony 1 , no triploids where found in the brood produced before $\mathrm{CO}_{2}$ narcosis (Table IV, genotypes in Table SIV) or in the first sampling 26 days post-narcosis. Genotypes of worker pupae harvested 84 days post-narcosis indicated that the original queen had been superceded. This new queen was the daughter or thelytokous granddaughter of the original $\mathrm{CO}_{2}$-treated queen since she shared one allele at each tested locus. Surprisingly, one triploid worker was found among the pupae of this young, un-narcotised, queen (Table IV, genotypes in Table SIV). This worker carried three alleles at three loci and was unequivocally triploid.

In colonies 2, 3 and 5, no triploids were found in any progeny, either pre- or post- $\mathrm{CO}_{2}$ narcosis of the queen (Table IV, Genotypes in Table SIV).

\subsection{Experiment 5. Is triploidy/thelytoky present in the first brood of a naturally mated queen?}

We found no triploid individuals in the 170 pupal daughters of the first broods of the two queens examined (Table $\mathrm{V}$, genotypes in Table SV).

Table IV. Effect of $\mathrm{CO}_{2}$ narcosis of the mother queen on the ploidy of offspring females in Capensis

\begin{tabular}{|c|c|c|c|c|c|}
\hline Colony & $\begin{array}{l}\text { Days } \\
\text { post- } \\
\text { narcosis }\end{array}$ & $\begin{array}{l}\text { Number of } \\
\text { progeny } \\
\text { genotyped }\end{array}$ & $\begin{array}{l}\text { Number of } \\
\text { progeny of the } \\
\text { treated queen }\end{array}$ & $\begin{array}{l}\text { Triploids in the } \\
\text { treated queen's } \\
\text { progeny }\end{array}$ & Comment \\
\hline \multirow[t]{3}{*}{1} & 0 & 96 & 95 & 0 & 1 pupa laid by a parasitic worker \\
\hline & 26 & 96 & 95 & 0 & 1 pupa laid by a parasitic worker \\
\hline & 84 & 96 & 0 & 0 & $\begin{array}{l}\text { Colony superseded by daughter } \\
\text { queen that laid one triploid } \\
\text { offspring }\end{array}$ \\
\hline \multirow[t]{3}{*}{2} & 0 & 96 & 96 & 0 & \\
\hline & 26 & 96 & 96 & 0 & \\
\hline & 87 & 96 & 88 & 0 & 8 pupae laid by a parasitic worker \\
\hline \multirow[t]{3}{*}{3} & 0 & 96 & 96 & 0 & \\
\hline & 26 & 96 & 96 & 0 & \\
\hline & 84 & 96 & 96 & 0 & \\
\hline \multirow[t]{2}{*}{5} & 0 & 96 & 93 & 0 & 3 pupae laid by a parasitic worker \\
\hline & 21 & 96 & 87 & 0 & 9 pupae laid by a parasitic worker \\
\hline
\end{tabular}


Table V. Frequency of triploidy in the first cycle of worker brood in the progeny of two naturally mated queens that were not subjected to $\mathrm{CO}_{2}$ narcosis

\begin{tabular}{llll}
\hline Queen & Pupae genotyped & Number of progeny of the treated queen & Triploid progeny of queen \% \\
\hline 1 & 96 & 76 & 0 \\
2 & 96 & 94 & 0 \\
\hline
\end{tabular}

\section{DISCUSSION}

The absence of thelytoky and triploidy in naturally mated Capensis queens (Beekman et al. 2008) is not prevented by the presence of semen in the spermatheca. Our evidence for this is twofold. First, in Experiment 1, virgin queens that had been laying thelytokous eggs prior to insemination continued to produce a high frequency of thelytokous eggs (i.e. diploid thelytokous and triploid thelytokous) after they had been inseminated $(45.9 \%$ of all non-arrhenotokous eggs). Second, we found one triploid pupae in the progeny of a naturally mated queen (the daughter of queen 1 in experiment, Table IV). This shows that the presence of semen in the spermatheca is insufficient to eliminate thelytokous reproduction in Capensis queens, as we have noted previously (Oldroyd et al. 2018). We must therefore consider alternative proximate mechanisms that prevent naturally mated Capensis queens from reproducing parthenogenetically. It is important to understand the mechanisms that prevent queen thelytoky since it is likely that a social insect species in which both queens and workers are thelytokous is evolutionarily unstable. Such a species is predicted to either lose the queen caste or go extinct (Goudie and Oldroyd 2018), yet the evolutionary incentive for queens to clone themselves when producing new queens is high (Greeff 1996; Fournier et al. 2005; Goudie and Oldroyd 2018). Since unmated queens can produce thelytokous eggs when narcotised, they clearly have the capacity to do so. Therefore, there must be a mechanism that prevents or minimizes thelytoky in queens that have mated.
In Experiment 1, the frequency of triploid eggs in queens induced to lay parthenogenetically by narcosis was $33.7 \%$ of fertilized eggs post-insemination. This frequency is similar to that seen the progeny of young Capensis queens that are instrumently inseminated (which includes narcosis during and post-insemination procedure) (5$33 \%$, Oldroyd et al. 2018). The question then arises as to the cause of the relatively high frequency of triploidy in the progeny of instrumentally inseminated Capensis queens. Is it $\mathrm{CO}_{2}$ narcosis per se, the lack of a mating flight or induced oviposition while virgin?

Our experiments show that when oviposition is induced by $\mathrm{CO}_{2}$ narcosis, the frequency of thelytoky and/or triploidy is greatly enhanced relative to that seen in naturally mated queens. However, narcotization of mature, naturally mated queens does not increase the frequency of thelytoky (Table IV). This strongly suggests that it is not $\mathrm{CO}_{2}$ narcosis itself that enhances the frequency of thelytoky and triploidy but the induction of oviposition without mating.

In Experiment 3, we showed that the frequency of thelytoky in artificially inseminated queens declines with time. The frequency of thelytoky/triploidy 4 months post-insemination was between 5 and $8 \%$ but declined to zero after 11 months. This suggests that the effects of induction of oviposition when virgin are transient. The frequency of thelytoky also declines (from a low base) in A. m. ligustica virgin queens that have been narcotised with $\mathrm{CO}_{2}$ (Tucker 1958).

In Experiment 2, we showed that virgin Capensis queens that are prevented from mating do not activate their ovaries, even after 1 month. This shows that Capensis queens do not use their ability to produce thelytokous eggs to commence laying when prevented from mating. Rather, it 
seems that thelytoky has been selected as a fitness-enhancing characteristic of queenless workers, because it allows social parasitism (Moritz et al. 1996; Moritz et al. 1998; Neumann et al. 2001; Jordan et al. 2008; Holmes et al. 2010; Moritz et al. 2011) and that queens have evolved to not switch on this preexisting capacity.

We note that in instrumentally inseminated Capensis queens (that have not been induced to lay prior to insemination as in Experiment 1), all thelytokous eggs laid in worker cells are fertilized to produce a triploid female. While triploid females are viable, most of their progeny are inviable (Oldroyd et al. 2018). If queens cannot withhold sperm when laying in a queen cell, so that they produce a clonal daughter queen, this may provide an indirect means of selection against thelytoky in queen Capensis.

Capensis is notable in that queens are strictly sexual, whereas the collective workers are thelytokous when queenless (Goudie and Oldroyd 2018). Four ant species in the genus Cataglyphis (Timmermans et al. 2008; Leniaud et al. 2011; Aron et al. 2013; Amor et al. 2017; Goudie and Oldroyd 2018) and Messor capitatus (Grasso et al. 2000) also fit this pattern. As explained above, such a social system can be stable over short evolutionary timescales because queens have equal relatedness $(0.5)$ to their daughters and thelytokously produced granddaughters and are therefore largely indifferent to worker reproduction, provided there is no reproductive parasitism by workers from other colonies. Workers too should have no preference between thelytokous worker reproduction by their sisters and sexual reproduction by their queen, provided that all subfamilies reproduce at similar frequencies and there is no reproductive parasitism. Because of the latter caveat, there is often extreme fighting among Capensis workers immediately after losing their queen (Anderson 1968), and queens dominate reproduction when they are present (Beekman et al. 2009). In contrast to Capensis, in the ant Cataglyphis pilliscapa (formerly C. cursor), both queens and workers are facultatively thelytokous (Pearcy et al. 2004; Doums et al.
2018). C. pilliscapa queens only use thelytoky to produce offspring queens, though many queens are produced sexually (Doums et al. 2013), thereby reducing the inbreeding of clonal queen lineages (Doums et al. 2018). C. pilliscapa is the only social insect species identified thus far in which both queens and workers are facultatively thelytokous in the absence of hybridogenesis (Goudie and Oldroyd 2018). (Hybridogenesis is a system in which queens obtain sperm from a different lineage in order to fertilize worker-destined eggs, Goudie 2018.) This system may be evolutionary stable because of extreme polyandry in in C. pilliscapa. On average, workers are more related to a thelytokous daughter of their queen (0.5) than to the thelytokous daughter of a half sister and so may prefer queen offspring. Like Capensis, they may therefore evolve to police worker reproduction when a queen is present (Pirk et al. 2003; Doums et al. 2013).

In conclusion, our results establish that induction of oviposition without mating is the key factor that initiates thelytoky in Capensis queens. It does not establish that $\mathrm{CO}_{2}$ narcosis is necessary to induce thelytoky (or triploidy in inseminated queens). Indeed, this possibility now seems unlikely since $\mathrm{CO}_{2}$ treatment of mature laying queens does not lead to thelytoky or triploidy. However, we note that $\mathrm{CO}_{2}$ narcosis has wide-ranging effects on the reproductive behaviour of insect's suppression of mating activity and oocyte development (Nicolas and Sillans 1989). A. mellifera workers exposed to $\mathrm{CO}_{2}$ have reduced fecundity and life span after narcotization (Harris and Harbo 1990; Harris et al. 1996; Koywiwattrakul et al. 2005). Curiously, in queens, $\mathrm{CO}_{2}$ narcosis has the opposite effect and enhances reproduction (Mackensen 1947; Engels et al. 1976; Kaftanoglu and Peng 1982; Woyke et al. 2001). To explicitly determine whether triploidy/thelytoky is induced by $\mathrm{CO}_{2}$ narcosis or by induction of oviposition without mating, it will be necessary to induce oviposition in Capensis queens without narcosis. This has been successfully achieved in A. m. carnica (Koeniger 1981), but whether it is possible to do so in Capensis is unknown. 


\section{ACKNOWLEDGEMENTS}

We thank Chris Fransman for beekeeping assistance.

\section{AUTHORS' CONTRIBUTIONS}

BPO, MB and MHA designed experiments. BPO, MB, MHA and RJR performed field work. SEA, RJR and GB performed genotyping and analysed data. SEA, RJR and BPO wrote the paper. TCW provided logistical support. All authors edited drafts of the paper.

\section{FUNDING INFORMATION}

This work was supported by Australian Research Council grant DP180101696 to B.P. Oldroyd and A. Zayed.

\section{DATA AVAILABILITY}

All genotyping data from this study are available as Supplementary Material.

Quels facteurs mécaniques affectent la parthénogenèse thélytoque chez les reines de Apis mellifera capensis?

\section{Apis mellifera / abeille mellifère / triploïdie / thélytoquie / parthénogenèse / haplodiploïdie.}

Welche mechanistischen Faktoren beeinflussen die thelytokische Parthenogenese bei Königinnen von Apis mellifera capensis?

Apis mellifera / Honigbiene / Triploidie / Thelytokie / Parthenogenese / Haplodiploidie.

\section{REFERENCES}

Allsopp M (1993) Summarized overview of the Capensis problem. S Afr Bee J 65:127-136

Amor F, Ortega P, Boulay R, Cerdá X (2017) Frequent colony orphaning triggers the production of replacement queens via worker thelytoky in a desert-dwelling ant. Ins Soc 64:373-378

Anderson R (1963) The laying worker in the Cape honeybee, Apis mellifera capensis . J Apic Res 2:85-92
Anderson R (1968) The effect of queen loss on colonies of Apis mellifera capensis. S Afr J Agric Sci 11:383-388

Aron S, Darras H, Eyer P-A, Leniaud L, Pearcy M (2013) Structure génétique des sociétés et systèmes d'accouplement chez la fourmi Cataglyphis viatica (Fabricius 1787). Bulletin de l'Institut Scientifique de Rabat 35:103-109

Beekman M, Allsopp M, Wossler T, Oldroyd B (2008) Factors affecting the dynamics of the honeybee (Apis mellifera) hybrid zone of South Africa. Heredity 100:13-18

Beekman M, Allsopp MH, Jordan LA, Lim J, Oldroyd BP (2009) A quantitative study of worker reproduction in queenright colonies of the Cape honey bee, Apis mellifera capensis. Mol Ecol 18:2722-2727

Beye M, Hasselmann M, Fondrk MK, Page RE, Omholt SW (2003) The gene csd is the primary signal for sexual development in the honeybee and encodes an SR-type protein. Cell 114:419-429

Cole-Clark MP, Barton DA, Allsopp MH, Beekman M, Gloag RS, Wossler TC, Ronai I, Smith N, Reid RJ, Oldroyd BP (2017) Cytogenetic basis of thelytoky in Apis mellifera capensis . Apidologie 48:623-624

Crewe R, Allsopp M (1994) Sex and the single queen: recent experiments with capensis and scutellata queens. S Afr Bee J 66:58-62

DeGrandi-Hoffman G, Erickson Jr E, Lusby D, Lusby E (1991) Thelytoky in a strain of US honey bees (Apis mellifera L. ). Bee Sci 1:166-171

Doums C, Cronin A, Ruel C, Fédérici P, Haussy C, Tirard C, Monnin T (2013) Facultative use of thelytokous parthenogenesis for queen production in the polyandrous ant Cataglyphis cursor. Journal of evolutionary biology 26:1431-1444

Doums C, Federici P, Chifflet-Belle P, Monnin T (2018) Worker thelytoky allows requeening of orphaned colonies but increases susceptibility to reproductive cheating in an ant. Animal behaviour 135:109-119

Engels W, Gonçalves LS, Engels E (1976) Effects of carbon dioxide on vitellogenin metabolism in unmated queen honeybees. J Apic Res 15:3-10

Eyer P-A, Leniaud L, Darras H, Aron S (2013) Hybridogenesis through thelytokous parthenogenesis in two Cataglyphis desert ants. Mol Ecol 22:947-955

Fournier D, Estoup A, Orivel J, Foucaud J (2005) Clonal reproduction by males and females in the little fire ant. Nature 435:1230

Gloag R, Tan K, Wang Y, Song W, Luo W, Buchman G, Beekman M, Oldroyd B (2017) No evidence of queen thelytoky following interspecific crosses of the honey bees Apis cerana and Apis mellifera. Ins Soc 64:241-246

Gloag RS, Remnant EJ, Oldroyd BP (2019) The frequency of thelytokous parthenogenesis in European-derived Apis mellifera virgin queens. Apidologie In press

Goudie F, Oldroyd BP (2014) Thelytoky in the honey bee. Apidologie 45:306-326 
Goudie F, Oldroyd BP (2018) The distribution of thelytoky, arrhenotoky and androgenesis among castes in the eusocial Hymenoptera. Ins Soc:1-12

Grasso DA, Wenseleers T, Mori A, Le Moli F, Billen J (2000) Thelytokous worker reproduction and lack of Wolbachia infection in the harvesting ant Messor capitatus. Ethology Ecology \& Evolution 12:309-314

Greeff JM (1996) Effects of thelytokous worker reproduction on kin-selection and conflict in the Cape honeybee, Apis mellifera capensis. Phil Trans R Soc B 351:617-625

Harbo JR (1986) Propagation and instrumental insemination. In: Rinderer TE (ed) Bee Genetics and Breeding. Academic Press, Orlando, pp 361-389

Harris JW, Harbo JR (1990) Suppression of ovary development of worker honeybees by association with workers treated with carbon dioxide. J Apic Res 29:187-193

Harris JW, Woodring J, Harbo JR (1996) Effects of carbon dioxide on levels of biogenic amines in the brains of queenless worker and virgin queen honey bees (Apis mellifera). J Apic Res 35:69-78

Hepburn H, Crewe R (1991) Portrait of the Cape honeybee, Apis mellifera capensis . Apidologie 22:567-580

Hepburn H, Jones G, Kirby R (1994) Introgression between Apis mellifera capensis Escholtz and Apis mellifera scutellata Lepeletier: the sting pheromones. Apidologie 25:557-565

Hepburn H, Radloff S, Fuchs S (1998) Population structure and the interface between Apis mellifera capensis and Apis mellifera scutellata . Apidologie 29:333-346

Hepburn HR (2001) The enigmatic Cape honey bee, Apis mellifera capensis . Bee World 82:181-191

Holmes MJ, Oldroyd BP, Allsopp MH, Lim J, Wossler TC, Beekman M (2010) Maternity of emergency queens in the Cape honey bee, Apis mellifera capensis . Mol Ecol 19:2792-2799

Holmes MJ, Tan K, Wang Z, Oldroyd BP, Beekman M (2015) Genetic reincarnation of workers as queens in the Eastern honeybee Apis cerana. Heredity 114:65

Jordan LA, Allsopp MH, Oldroyd BP, Wossler TC, Beekman M (2007) Cheating honeybee workers produce royal offspring. Proceedings of the Royal Society B: Biological Sciences 275:345-351

Jordan LA, Allsopp MH, Oldroyd BP, Wossler TC, Beekman M (2008) Cheating honeybee workers produce royal offspring. Proc R Soc Lond [Biol] 275:345351

Kaftanoglu O, Peng Y-S (1982) Effects of insemination on the initiation of oviposition in the queen honeybee. $\mathrm{J}$ Apic Res 21:3-6

Kobayashi K, Hasegawa E, Ohkawara K (2008) Clonal reproduction by males of the ant Vollenhovia emeryi (Wheeler). Ent Sci 11:167-172

Koeniger G (1981) In welchem Abschnitt des Paarungsverhaltens der Bienenkönigin findet die
Induktion der Eiablage statt? Apidologie 12:329343

Koywiwattrakul P, Thompson GJ, Sitthipraneed S, Oldroyd BP, Maleszka R (2005) Effects of carbon dioxide narcosis on ovary activation and gene expression in worker honeybees, Apis mellifera. J Insect Sci 5:36

Kronauer DJ, Pierce NE, Keller L (2012) Asexual reproduction in introduced and native populations of the ant Cerapachys biroi. Mol Ecol 21:5221-5235

Lacy KD, Shoemaker D, Ross KG (2019) Joint Evolution of Asexuality and Queen Number in an Ant. Current Biology 29:1394-1400. e4

Laidlaw HH, Page RE (1997) Queen rearing and bee breeding

Leniaud L, Darras H, Boulay R, Aron S (2012) Social hybridogenesis in the clonal ant Cataglyphis hispanica. Current Biology 22:1188-1193

Leniaud L, Heftez A, Grumiau L, Aron S (2011) Multiple mating and supercoloniality in Cataglyphis desert ants. Biological Journal of the Linnean Society 104:866-876

Mackensen O (1943) The occurrence of parthenogenetic females in some strains of honeybees. J Econ Ent 36:465-467

Mackensen O (1947) Effect of carbon dioxide on initial oviposition of artificially inseminated and virgin queen bees. J Econ Ent 40:344-349

Moritz R, Beye M, Hepburn H (1998) Estimating the contribution of laying workers to population fitness in African honeybees (Apis mellifera) with molecular markers. Ins Soc 45:277-287

Moritz RF, Kryger P, Allsopp MH (1996) Competition for royalty in bees. Nature $384: 31$

Moritz RF, Lattorff HMG, Crous KL, Hepburn RH (2011) Social parasitism of queens and workers in the Cape honeybee (Apis mellifera capensis). Behav Ecol Sociobiol 65:735-740

Neumann P, Radloff SE, Moritz RF, Hepburn HR, Reece SL (2001) Social parasitism by honeybee workers (Apis mellifera capensis Escholtz): host finding and resistance of hybrid host colonies. Behav Ecol 12:419-428

Nicolas G, Sillans D (1989) Immediate and latent effects of carbon dioxide on insects. Annu Rev Entomol 34:97-116

Okita I, Tsuchida K (2016) Clonal reproduction with androgenesis and somatic recombination: the case of the ant Cardiocondyla kagutsuchi. Sci Nat 103:22

Oldroyd BP, Aamidor SE, Buchmann G, Allsopp MH, Remnant EJ, Kao FF, Reid RJ, Beekman M (2018) Viable Triploid Honey Bees (Apis mellifera capensis) Are Reliably Produced in the Progeny of $\mathrm{CO} 2$ Narcotised Queens. G3-Genes, Genom, Genet 8:3357-3366

Oldroyd BP, Allsopp MH, Gloag RS, Lim J, Jordan LA, Beekman M (2008) Thelytokous parthenogenesis in unmated queen honeybees (Apis mellifera capensis): 
central fusion and high recombination rates. Genetics 180:359-366

Oldroyd BP, Fewell JH (2007) Genetic diversity promotes homeostasis in insect colonies. Trends Ecol Evol 22:408-413

Pearcy M, Aron S, Doums C, Keller L (2004) Conditional use of sex and parthenogenesis for worker and queen production in ants. Science 306:1780-1783

Pearcy M, Hardy O, Aron S (2006) Thelytokous parthenogenesis and its consequences on inbreeding in an ant. Heredity 96:377

Pirk C, Neumann P, Ratnieks F (2003) Cape honeybees, Apis mellifera capensis, police worker-laid eggs despite the absence of relatedness benefits. Behav Ecol $14: 347-352$

Rabeling C, Kronauer DJ (2013) Thelytokous parthenogenesis in eusocial Hymenoptera. Annu Rev Entomol 58:273-292

Shaibi T, Lattorff H, Moritz R (2008) A microsatellite DNA toolkit for studying population structure in Apis mellifera. Mol Ecol Res 8:1034-1036

Solignac M, Vautrin D, Loiseau A, Mougel F, Baudry E, Estoup A, Garnery L, Haberl M, Cornuet JM (2003) Five hundred and fifty microsatellite markers for the study of the honeybee (Apis mellifera L.) genome. Mol Ecol Notes 3:307-311
Timmermans I, Hefetz A, Fournier D, Aron S (2008) Population genetic structure, worker reproduction and thelytokous parthenogenesis in the desert ant Cataglyphis sabulosa. Heredity 101:490

Tucker KW (1958) Automictic parthenogenesis in the honey bee. Genetics 43:299

Verma S, Ruttner F (1983) Cytological analysis of the thelytokous parthenogenesis in the Cape honeybee (Apis mellifera capensis Escholtz). Apidologie 14:41-57

Walsh PS, Metzger DA, Higuchi R (1991) Chelex 100 as a medium for simple extraction of DNA for PCR-based typing from forensic material. Biotechniques 10:506-513

Woyke J, Fliszkiewicz C, Jasiñski Z (2001) Prevention of natural mating of instrumentally inseminated queen honeybees by proper method of instrumental insemination. J Apic Sci 45:101-114

Zar JH (1996) Biostatistical Analysis. Prentice-Hall, Upper Saddle River

Publisher's note Springer Nature remains neutral with regard to jurisdictional claims in published maps and institutional affiliations. 